\title{
Emerging Market Multinationals and the Concept of Ownership Advantages
}

\author{
Peter J Williamson and Feng Wan
}

\section{Introduction}

The concept of ownership advantages lies at the core of much of the theory concerning the competitiveness, and even the existence, of multinational enterprises (Dunning, 1980; Lundan 2010). Yet despite the growth and success of multinationals from emerging markets (EMNEs) in the past decade, many scholars have argued that they lack ownership advantages (Madhok \& Keyhani, 2012; Mathews, 2002; Rugman, 2009). In this viewpoint article we revisit this apparent paradox.

Based on preliminary analysis of the competitive advantages that underpin the international expansion of a set of Chinese EMNEs, we argue that the concept of ownership advantages needs to be broadened beyond traditional definitions of technology and brands to encompass capabilities such as cost innovation (Williamson \& Zeng, 2009; Zeng \& Williamson, 2007), accelerated innovation (Williamson \& Yin, 2014), optimizing products and processes for local customers (Ramamurti, 2009), and filling institutional voids (CuervoCazurra \& Genc, 2008; Morck, Yeung, \& Zhao, 2008). We argue that EMNEs often build these non-traditional ownership advantages by accessing locational advantages in their home markets that are available only to firms with locally-complementary resources. They then convert these locational advantages into ownership advantages through innovation and learning. The resulting ownership advantages can be deployed to underpin successful international expansion. 


\section{Non-traditional ownership advantages}

A preliminary analysis of the successful international expansion of a sample of Chinese EMNEs (at least in terms of market seeking and hence their ability win share in overseas markets) suggests this is underpinned by a number of different types of non-traditional ownership advantages categorised in Table 1. Those non-traditional ownership advantages include cost innovation, accelerated innovation, and optimizing products and processes for local customers.

Cost innovation has been defined as: "the strategy of using Chinese cost advantage in radically new ways to offer customers around the world dramatically more for less" (Zeng \& Williamson, 2007: p1). A good example of cost innovation is the maker of electric vehicles, BYD which sold the most electric cars in 2016, exceeding Silicon Valley's Tesla, according to Bloomberg New Energy Finance (Fehrebacker, 2017). BYD's cost innovation capability stems from its process innovations in manufacturing that are exploited through a verticallyintegrated business model. Unlike most carmakers that rely on a network of third-party component suppliers, BYD produces almost all parts of its cars in-house, from electric vehicle batteries, transmission systems, steering systems, and braking systems, to wipers, indicator mirrors, and even CD and DVD players. The only exceptions are tyres, windshields, and a few of the most generic components. By re-designing its manufacturing processes and tightly integrating them, BYD has been able to leverage the low cost but skilled workers in China across activities in the entire value chain.

The second type is accelerated innovation, which is reengineering research and development and innovation processes to make new product development dramatically faster and less costly. This is achieved by industrialising the new product development process by dividing it down to into a multitude of small steps each with a large number of 
staff dedicated to each, pushing the boundaries of simultaneous engineering to cut the lead times for new product development, initiating rapid "launch-test-improve" cycles to move down the learning curve faster, and restructuring the organization around flexible project teams to speed up problem solving (Williamson \& Yin, 2014). Such approaches are unlikely to generate stunning technological breakthroughs, but it allows Chinese competitors to cut the time it takes to bring innovative products and services to mainstream markets. It also represents a new way of deploying Chinese cost and volume advantages in global competition. Consider Lenovo Group Ltd., which acquired IBM's personal computer business in 2005 and is headquartered in Beijing and Morrisville, North Carolina. In 2005, its new product development cycle was 12 to 18 months. Since then, Lenovo has managed to cut the cycle in half by applying simultaneous engineering across the entire innovation process, beginning in R\&D and continuing through design, manufacturing engineering, quality control, procurement, marketing and service. For every project, team members work on different elements in parallel, under the supervision of one leader. Lenovo overcomes the usual problems of implementation by breaking down its product designs into separable modules linked by standardized interfaces; redesigning its software to be compatible across all activities associated with the new product; establishing short lines of communication where each team member can represent his or her respective functional department; and introducing open design processes where information is shared with the entire team as early as possible (Williamson \& Yin, 2014).

Another type of non-traditional advantage we find in Chinese firms is the capability to optimize products and processes for local customers and offer unmatched choice of products into what used be considered standardized, mass-market segments. They achieve this by drawing on the abundance of relatively low-cost engineers available in China and by 
developing flexible processes to reduce the fixed costs of launching a new product variant. The harbour machinery maker Shanghai Zhenhua Port Machinery Company (ZPMC), for example, hired 800 design engineers - between 20 and 40 times the number of design staff employed by their German and Italian competitors. This massive engineering resource allowed ZPMC to offer a far wider product range than its European rivals, and to be able to customise its equipment to the particular requirements of any port operator's site - all at a similar price as standardised machinery. Haier meanwhile, now the leading white goods manufacturer in the world, for example, first penetrated the U.S. market back in 1994 with compact refrigerators that it optimized for student dormitories in New York where high property price meant there was insufficient space to accommodate regular-sized refrigerators. This category had been neglected by the incumbent competitors whose high set-up costs made it uneconomic to serve this low-priced segment. Haier, however, was able to engineer its production lines, sometimes adding flexible manual steps, to substantially reduce the cost of set-up and model change-over giving it an advantage in unlocking this underserved demand. It subsequently extended this segment-specific differentiation by adding features such as a folding table on top of the fridge - further serving the specific needs of students short of space. Once the compact refrigerator became successful, Haier was able to build on this base to sell other products in the U.S. market.

\section{The role of differential access to location advantages}

The logical next question is where do EMNEs' non-traditional advantages come from? Drawing on the resource-based view of the firm (Barney, 1991; Teece, Pisano, \& Shuen, 1997; Wernerfelt, 1984), Rugman, Verbeke and Nguyen (2011) have suggested that 
locational advantages in a country can lead firms operating locally to create new, locationbound ownership advantages. This literature also suggests that some locational advantages have the potential to be transformed into non-location-bound ownership advantages. Porter (1991) explained that locational advantages often provide the raw materials from which ownership advantages are created by firms, stating that: "We observe striking concentrations of successful firms in a particular industry in particular locations, which suggests that something about these locations are fundamental to creating and sustaining advantage...Instead of solely within the firm, the true origin of competitive advantage may be the proximate or local environment in which a firm is based" (Porter, 1991: 96-110).

The intellectual antecedents of locational advantages date back at least to Alfred Marshall, who noticed that in late nineteenth century Britain firms involved in manufacturing a particular type of product tended to be geographically clustered (Marshall, 1890). To explain this phenomenon Marshall postulated the benefits such a cluster (or what he termed an "industrial district") would have to firms located there. These advantages included access to specialist, skilled labour attracted by the wealth of opportunities available in the industrial district and to the accumulation of knowledge locally that is facilitated by the exchange of relevant and innovation through colocation ("The mysteries of the trade become no mysteries; but are as it were in the air", Marshall, 1890, Ch. 10). Locational advantages have also been shown by Raymond Vernon and his colleagues at Harvard (Vernon, 1966, 1974; Wells, 1983), to be important determinants of foreign direct investment. More recently, in Dunning's (1980) influential OLI model, locational advantages are one of the three factors explaining an enterprise's competitiveness in foreign markets.

Potential locational advantages include not only Ricardian type endowments - such as land, labour, capital, but also aspects of the legal and commercial environment in which 
the firm is based, such as market structure, government legislation and policies (Dunning, 1980). In the seminal book the Competitive Advantage of Nations, Porter (1990) argued that locational advantages could be classified into six categories: 'factor conditions', 'demand conditions', 'related and supporting industries', 'firm strategy, structure, and rivalry', 'the role of chance', and 'the role of government', a classification that has been widely adopted (Rugman \& Collinson, 2009; Rugman, Oh, \& Lim, 2012). These locational advantages will shape the information that firms have available to perceive opportunities and the pools of inputs, skills and knowledge they can draw on.

Researchers have, however, recognized that some locational advantages are not freely and fully available to all firms operating in the same location (Crilly, Ni, \& Jiang, 2016; Hennart, 2009, 2012; Johanson \& Vahlne, 2009; Porter, 1990; Zaheer, 1995; Zaheer \& Nachum, 2011; Zhou \& Guillen, 2014). We argue that some domestic firms may have superior access to locational advantages than other firms (such as multinationals from developed countries) operating in the same location for several reasons. First, some domestic firms will enjoy better access to locational advantages at home because they have greater stocks of experiential and context-dependent, complementary local knowledge. Second, some domestic firms will be more capable of accessing locational advantages at home because of a closer relationship with the related and supporting industries and the local government. Third, some domestic firms will be more capable than multinationals from advanced economies in accessing locational advantages at home because of their home-focused strategies, while multinationals from advanced economies tend to pursue HQ-imposed strategies that ignore or reduce their ability to access local locational advantages because of their desire to exploit ownership advantages transferred from overseas. 
Most of the non-traditional advantages discussed above have their roots in the superior capability of Chinese companies to recruit, train and motivate large numbers of low-cost engineers available in China (one of Porter's factor conditions) and utilise them to deliver incremental process innovation or product redesign quickly and efficiently. They can do so because of complementary knowledge and networks relevant to the local environment. The Chinese companies we studied also displayed a willingness to flexibly adjust their strategies to maximise the opportunities to exploit potential local advantages. These include Porter's demand conditions, such as customers who demand extreme value for money but who are also willing to experiment with new products and little known brands. Local potential advantages also include the availability of a large and deep pool of competent and highly responsive suppliers in China (Porter's "related and supporting industries") that enable Chinese firms to establish and reconfigure low-cost supply chains for new product variants quickly and efficiently.

\section{From locational advantages to ownership advantages}

Accessing locational advantages is only the first step towards creating ownership advantages. Potential EMNEs are those firms that can convert those locational advantages into ownership advantages. To do so they use various types of dynamic capabilities that enable them to respond to the rapidly changing and high competitive local market environment with the aim of creating and sustaining ownership advantages. Williamson (2016) suggests that some Chinese EMNEs possess a variety of dynamic capabilities to convert locational advantages into ownership advantages. The dynamic capabilities we 
observed parallel the three categories: sensing, seizing of opportunities, and the transformation of resource and organizational configurations proposed by Teece (2007). The first of these dynamic capabilities we observed is the ability to sense fastchanging market opportunities by using rapid 'launch-sense-improve' cycles. Traditional approaches to sensing and responding to shifts in consumer demand tend to focus on extensive market research, which is then assessed and fed into an extended product development process designed to maximize the probability of successfully launching a new offering that will generate revenue and profits over an extended period with minimal redesign (Achrol \& Kotler, 1999; Kotler \& K.L., 2006). Chinese EMNEs often adopt a strategy of launching new products into the market as soon as possible, even before the offering was fully developed, immediately sensing customer's reactions (often through real-time electronic channels such as social media), quickly designing and incorporating improvements based on that feedback, and relaunching a new version into the market. Utilising this experience, they built a dynamic capability in managing rapid iterations of this 'launch-sense-improve cycle,' enabling them to sense and respond to rapidly evolving customer preferences. This allowed them to take leverage the locational advantage to which they had access of Chinese consumers with a high willingness to experiment and to transform this into an ownership advantage in the form of a stream of new products that closely matched the rapid evolution of consumer preferences.

The second dynamic capability is the ability to seize opportunities quickly and at low cost, based on reengineering of the product development process by applying the lessons of flexible manufacturing, modularization, and simultaneous engineering. Reengineering R\&D and product development in these ways enables the huge pool of engineers and other staff available in China to by leveraged to increase flexibility and speed. This has enabled leading 
Chinese EMNEs to develop dynamic capabilities in seizing opportunities for cost, application, and business model innovation at much lower levels of investment and more rapidly than would be possible using traditional R\&D processes that are optimized to develop breakthrough technologies, improved functionality, and more sophisticated products. These dynamic capabilities thus enable some Chinese firms to convert their local factor conditions (the availability of large pool of relatively low-cost engineers) into an ownership advantage in the form of incremental innovation at lower cost and greater speed than their competition.

The third dynamic capability is the ability to accelerate transformation based on flexible organizational processes that combine vertical hierarchy with horizontal coordination. The organization structures of Chinese EMNEs tend to be more hierarchical than its Western counterparts. Often a single, senior individual overlooks the entire innovation process and his/her word is proverbial 'law'. Such dependence on the judgement of a single executive increases the risk that innovation initiatives end up moving in a completely unproductive direction. But this hierarchical structure and decision making does speed up the process of initiating, developing, and launching innovations. Equally important, we observed that in the innovation processes adopted by Chinese EMNEs, this vertical determinism was complemented with extreme horizontal flexibility in marshalling and recombining resources from different departments and functions horizontally across the organization behind a favoured idea. Whenever a problem arose in the innovation process, the most common approach for Chinese EMNEs was to call for an immediate meeting attended by heads of relevant departments. A quick diagnosis was then performed and solutions often swiftly decided upon, after which immediate action is taken by the participating party (in large part because of intense pressure from the vertical hierarchy on 
the entire group to deliver). This process might be dubbed 'huddle-and-act'. It underpins continuous renewal in many of Chinese EMNEs. It enables them to rapidly scale up new innovations by quickly and efficiently overcoming obstacles that are often faced in moving from a prototype to mass-manufacturing and wide distribution. This, in turn, allows them to thrive under demand conditions where mass-market customers require extreme levels of value for money and a continuous flow of "fresh" product and service offerings.

As a result of these differential capabilities to access locational advantages and then to convert them into ownership advantages using distinctive dynamic capabilities, EMNEs are likely to have at their disposal a different vector of ownership advantages compared to multinationals from advanced economies. Specifically, each of the dynamic capabilities identified above contributes to the accumulation of non-traditional ownership advantages such as cost innovation, accelerated innovation, and optimising products and processes for local customers. These contrast with the advantages that predominate in MNEs from developed countries: proprietary technology and brands. Indeed, the very fact that most MNEs from developed countries concentrate on building ownership advantages based on superior technology and strong brands using resources and capabilities abundant in their home markets and the project these advantages into overseas markets (Doz, et. al., 2001), may hinder their ability to develop the kinds of non-traditional advantages EMNEs enjoy. The non-traditional ownership advantage of optimising products and processes for local customers, for example, would require reverse knowledge transfer inside established MNEs from the developed world and high levels of headquarters absorptive capacity - a combination which previous studies suggest is rare in incumbent multinational firms (Yang, et. al., 2008). 


\section{Ownership advantages and EMNEs internationalisation}

Only some of the ownership advantages amassed in the home market will be non-location bound (Cuervo-Cazurra et al., 2007). It is these non-traditional, non-location bound ownership advantages that enable companies to become EMNEs. Haier, for example, was able to use its advantages in reducing set-up and changeover costs to unlock underserved segments in foreign markets such as dedicated wine-storage refrigerators a product category where it now leads the market in both North America and Asia. Those nontraditional ownership advantages are further improved and developed by EMNEs by going global because their first priority in internationalisation is usually strategic asset seeking (Rui \& Yip, 2008; Deng, 2009). This enables 'learning from the world' and enhanced innovation capability, which is only later followed market exploitation abroad (Williamson, 2014). The non-traditional ownership advantages we have identified tend to be more relevant to certain international markets (especially other emerging markets) and market segments (the value-for-money segment). So that is where EMNEs tend to exploit their ownership advantages first. But these markets and market segments are expanding fastest for two reasons. First, emerging markets, especially the BRIC (Brazil, Russia, India, and China) and VISTA (Vietnam, Indonesia, South Africa, Turkey, and Argentina) countries, are becoming increasingly important as drivers of demand. As the Economist magazine has pointed out, already by 2005 the combined GDP of emerging and developing economies had risen to above half of global GDP when measured at purchasing-power parity (Economist, 2010). The capabilities to succeed in emerging markets, therefore, will be decisive in the next round of global competition (Knight \& Cavusgil, 2004). 
A second important shift in the global market that might favour the ownership advantages of EMNEs stems from the fact that China's 1.3 billion people (including a potentially active labour force of 800 million) cannot move from economic isolation to become an integrated part of the world economy without a downward pressure on global labour rates. And that process, which began in 1978 when China started to open up to the world, still has a long way to go: there are still at least 500 million Chinese still to move from low-productivity agriculture to be efficiently employed in manufacturing and services. That's before we even take account of another 1 billion that might make this transition in India and other developing countries over the next decades. While these shifts continue, and there is little reason to suppose they will stop, at the macro level downward pressure on wages will continue. These forces have led real income levels of a significant segment of the working population in the developed world to stall or even to decline (especially among less-skilled workers in the North America and Europe). Many also feel their job security is under threat. As a result, a substantial, and growing, market segment of consumers in the developed world have become acutely focused on seeking out the lowest prices and best value for money. At the same time, they want to maintain interest and excitement by being able to choose products they see as keeping up with new trends and are loath to restrict their choice of variety. EMNEs may be better equipped to proper from this growing segment that demands 'everyday low prices' and increased value for money for innovative products and commodities than developed country multinationals with more traditional ownership advantages that underpin higherpriced, differential offerings.

\section{Conclusion}


We need to broaden our concept of ownership advantages. We also need to re-think where ownership advantages come from (antecedents are locational advantages and differential ability to access these). To build the capacity to succeed abroad EMNEs also requires dynamic capabilities to convert their locational advantages into non-location bound ownership advantages that can be transferred overseas.

As a viewpoint article, we hope this work will stimulate further research. By its very nature, the analysis has limitations: our assessment of the ownership advantages underpinning EMNEs success is to some degree subjective; the sample is also limited. Future research could valuably test the arguments laid out in this paper with a larger sample and a more developed methodology for identifying, classifying and measuring non-traditional ownership advantages. 


\section{References}

Achrol, R., \& Kotler, P. 1999. Marketing in the network economy. Journal of Marketing, 63: 146-163.

Barney, J. 1991. Firm Resources and Sustained Competitive Advantage. Journal of Management, 17(1): 99-120.

Crilly, D., Ni, N., \& Jiang, Y. 2016. Do-no-harm versus do-good social responsibility: Attributional thinking and the liability of foreignness. Strategic Management Journal, 37: 1316-1329.

Cuervo-Cazurra A., Maloney M. M., \& Manrakhan S. 2007. Causes of the difficulties in internationalization. Journal of International Business Studies, 38(5): 709-725.

Cuervo-Cazurra, A., \& Genc, M. 2008. Transforming disadvantages into advantages: developing -country MNEs in the least developed countries. Journal of International Business Studies, 39: 957-979.

Deng, P. 2009. Why do Chinese firms tend to acquire strategic assets in international expansion?, Journal of World Business, 44: 74-84.

Doz, Y., Santos, J. and Williamson, P. 2001. From Global to Metanational: How companies win in the global knowledge economy, Boston: HBS Press.

Dunning, J. H. 1980. Toward an Eclectic Theory of International Production: Some Empirical Tests. Journal of International Business Studies, 11(1): 9-31.

Economist (The), 2010. Networked Networks. Economist Print edition, 17 April: 17.

Hennart, J. 2009. Down with MNE-centric theories! market entry and expansion as the building of MNE and local assets. Journal of International Business Studies, 40(9): 1432-1454.

Fehrenbacher, K., 2017. Tesla, BYD jockey for electric car world domination. Greentechmedia, https://www.greentechmedia.com/articles/read/tesla-byd-jockeyfor-electric-car-world-domination, Accessed 26 April, 2017.

Hennart, J. 2012. Emerging market multinationals and the theory of the multinational enterprise. Global Strategy Journal, 2(3): 168-187.

Johanson, J., \& Vahlne, J. 2009. The Uppsala internationlization process model revisited: from liability of foreignness to liability of outsidership. Journal of International Business Studies, 40: 1411-1431.

Knight, G. A., \& Cavusgil, S. T. 2004. Innovation, organizational capabilities, and the bornglobal firm. Journal of International Business Studies, 35(2): 124-141.

Kotler, P., \& K.L., K. 2006. Marketing Management. New York: Pearson.

Lundan,S.M. 2010. What are Ownership Advantages?, Multinational Business Review, 18(2): 51-70

Madhok, A., \& Keyhani, M. 2012. Acquisitions as entrepreneurship: asymmetrics, opportunities, and the internationalization of multinationals from emerging economics. Global Strategy Journal, 2(1): 26-40.

Marshall, A. 1890. Principles of economics. London: Macmillan.

Mathews, J. A. 2002. Competitive Advantages of the Latecomer Firm: A Resource-Based Account of Industrial Catch-Up Strategies. Asia Pacific Journal of Management, 19: 467-488.

Morck, R., Yeung, B., \& Zhao, M. 2008. Perspectives on China's outward foreign direct investment. Journal of International Business Studies, 39: 337-350.

Porter, M. E. 1990. The competitive advantage of nations. Harvard Business Review. 
Ramamurti, R. 2009. What have we learned about emerging market MNEs? In R. Ramamurti, \& J. Singh (Eds.), Emerging multinationals in emerging markets: $399-$ 426. Cambridge, U.K.: Cambridge University Press.

Rugman, A. M. 2009. Theoretical aspects of MNEs from emerging markets. In R. Ramamurti, \& J. Singh (Eds.), Emerging Multinationals in Emerging Markets: 42-63: Cambridge University Press.

Rugman, A. M., \& Collinson, S. 2009. International Business, 4ed.: Financial Times/ Prentice Hall.

Rugman, A. M., Oh, C., \& Lim, D. 2012. The regional and global competitiveness of multinational firms. Journal of the Academy of Marking Science, 40: 218-235.

Rui, H. and G.S. Yip, 2008. "Foreign acquisitions by Chinese firms: A strategic intent perspective", Journal of World Business, 43: 213-226.

Teece D.J., 2007. Explicating dynamic capabilities: the nature and microfoundations of (sustainable) enterprise performance. Strategic Management Journal, 28(13): 13191350.

Teece, D. J., Pisano, G., \& Shuen, A. 1997. Dynamic Capabilities and Strategic Management. Strategic Management Journal, 18(7): 509-533.

Vernon, R. 1966. International investment and international trade in the product cycle. The Quarterly Journal of Economics, 80(2): 190-207.

Vernon, R. 1974. Competition policy toward multinational corporations. American Economic Review, 64(2): 276-282.

Wells, L. T. 1983. Third world multinationals: Cambridge, MA: MIT Press.

Wernerfelt, B. 1984. A Resource-based View of the Firm. Strategic Management Journal, 5(2): 171-180.

Williamson, P., \& Zeng, M. 2009. Chinese multinationals: emerging through new global gateways. In R. Ramamurti, \& J. Singh (Eds.), Emerging Multinationals in Emerging Markets: 81-109. UK: Cambridge University Press.

Williamson, P. J. 2014. The internationalization of EMNCs: different drivers? In A. CuervoCazurra, \& R. Ramamurti (Eds.), Understanding Multinationals from Emerging Markets: Cambridge University Press.

Williamson, P. J., \& Yin, E. 2014. Accelerated innovation: the new challenge from China. MIT Sloan Management Review, 55(4): 1-8.

Williamson, P. J. 2016. Building and leveraging dynamic capabilities: Insights from accelerated innovation in China, Global Strategy Journal, 6: 197-210.

Yang, Q., Mudambi, R., \& Meyer, K.E., Conventional and Reverse Knowledge Flows in Multinational Corporations. Journal of Management, 34(5): 882-902.

Zaheer, S. 1995. Overcoming the liability of foreignness. Academy of Management Journal, 38(2): 341-363.

Zaheer, S., \& Nachum, L. 2011. Sense of place: from location resources to MNE locational capital. Global Strategy Journal 1: 96-108.

Zeng, M., \& Williamson, P. J. 2007. Dragons At Your Door: How Chinese Cost Innovation Is Disrupting Global Competition. Boston, MA: Harvard Business School Press.

Zhou, N., \& Guillen, M. F. 2014. From home country to home base: A dynamic approach to the liability of foreignness. Strategic Management Journal, 36(6): 907-917. 
Table 1

Non-traditional ownership advantages with representative cases

\begin{tabular}{|c|c|c|}
\hline Case firms & Non-traditional ownership advantages & International market shares* \\
\hline BYD & Cost innovation & $\begin{array}{l}\text { No. } 1(15 \%) \text { in the electric vehicle } \\
\text { industry by sales volumes in } 2016\end{array}$ \\
\hline Hi-Sense & Cost innovation & $\begin{array}{l}\text { No. } 4(4.10 \%) \text { in the TV industry in } \\
2015 \text {, after Samsung, LG, and Sony }\end{array}$ \\
\hline Huawei & Accelerated innovation & $\begin{array}{l}\text { No. } 3(8.20 \%) \text { in the smart phone } \\
\text { industry in } 2016 \text {, after Samsung and } \\
\text { Apple }\end{array}$ \\
\hline Lenovo & Accelerated innovation & $\begin{array}{l}\text { No. } 1(20.10 \%) \text { in the PC industry in } \\
2016\end{array}$ \\
\hline Haier & $\begin{array}{l}\text { Optimizing products and processes for } \\
\text { local customers }\end{array}$ & $\begin{array}{l}\text { No. } 1(15.70 \%) \text { in the fridge industry } \\
\text { in } 2015\end{array}$ \\
\hline Goldwind & $\begin{array}{l}\text { Optimizing products and processes for } \\
\text { local customers }\end{array}$ & $\begin{array}{l}\text { No. } 1(12.6 \%) \text { in the wind turbine } \\
\text { industry in } 2015\end{array}$ \\
\hline
\end{tabular}

* Based on sources including Euromonitor and Bloomberg 